\title{
REPRÆSENTATION ELLER BELÆRING?
}

\author{
Jørgen Hein
}

Enevaldens Danmark havde to store samlinger, Rosenborg og Kunstkammeret, der begge havde et betydeligt indhold af kunsthåndvark. Hvor gik skillelinjen? Hvad var deres opgaver?

Fyrstesamlinger blev en del af undersåtternes identitet og danner grundstammen $i$ mange museer, hvorfor deres indhold har stor museologisk interesse. En dominerende tendens $i$ den sidste generations forskning har varet studiet af renassancens kunstkamre, hvis grundidé var at lade udvalgte genstande afspejle menneskets viden og forestillinger om omverdenen. Dette nybrud, der forudsatte klassifikation af genstande og strukturering af viden, har delvist skygget for, at mange kunstkamre kun havde en kort levetid. Allerede 0.1600 blev de betydeligste forenet med eller måtte afgive de bedste af deres genstande til skatkammersamlinger, der stod direkte under fyrstens kontrol og havde reprasentation som det primare formål. Udtrykt starkt forenklet fik skatkammeret en renassance i barokken.

Denne udvikling fik også konsekvenser for Danmark, hvor samlingshistorie traditionelt er synonym med Frederik III's Kunstkammer, der blev grundlagt på Københavns Slot o. 1650. Enevælden havde imidlertid også et skatkammer, der blev indrettet på Rosenborg o. 1660 og hurtigt fik et betydeligt indhold af kunsthåndværk og paradevåben. Internationalt var de to samlinger således sildefødinge, hvorfor disse overlapninger kan undre. I det følgende skal de sammenlignes, og det skal påvises, at der o. 1690 blev fastlagt principper for fordelingen af kunsthåndværk, som varede frem til grundlæggelsen af dansk museumsvæsen i 1820'rne. Sagt med andre ord er emnet den dynastisk-nationale arv, eller udtrykt mere præcist, den kongelige arvegang og samlen 1520-1820. På den ene side Kunstkammeret som offentliggjort af Bente Gundestrup $1991^{1}$, på den anden side skatkammersamlingen på Rosenborg som behandlet af Gudmund Boesen og nærværende forfatter. $^{2}$

For tydelighedens skyld skal de to samlingstyper defineres.

Ved et skatkammer forstås en ophobning af kostbare genstande under fyrstens kontrol, der iscenesættes med pomp og pragt og kun er tilgængelig for de udvalgte få. Ved et Kunstkammer forstås en samling, hvis genstande 
154 indsamles og opstilles efter bestemte principper, der afspejler menneskets viden og forestillinger om omverdenen. Målet er belæring af en bredere offentlighed som udtrykt i Kunstkammerets opdeling i tematiske kamre, hvis genstande viste den besøgende et verdensbillede i miniature. Følgelig er de væsentligste forskelle, at Skatkammeret skal repræsentere og kan udgøre en kapitalreserve i nødstider, mens Kunstkammerets grundidé er strukturering og formidling af viden.

Akcepteres disse definitioner, kan den kongelige danske arv struktureres som en toleddet størrelse, opdelt i 1. en institutionellinje, kongemagtens samlinger (Rosenborg, Kunstkammeret, Det kgl. Bibliotek, Tøjhuset o.s.v.) og i 2. en privat linje, de kongeliges personlige kostbarheder og bohave, der udsmykkede deres gemakker og kunne nedarves inden for familien gennem generationer. Denne opdeling kan synes indlysende, men den har væsentlige konsekvenser, idet de kongeliges dødsboer var vigtige fødelinjer for de institutionelle samlinger. Og i denne sammenhæng ses en alvorlig kildemæssig skævhed: Kun én af valgkongerne har efterladt en bofortegnelse (Frederik I 1533), og med enevælden 1660 indførtes førstefødselsretten, hvorfor kongens bo aldrig blev opgjort. Dødsboer, der kan tjene som vejskilte på genstandenes færd til nutiden, eksisterer kun for enkedronninger og for ugifte prinsesser. Derved kommer kvinderne måske til at spille en større rolle $\mathrm{i}$ eftertiden end i samtiden.

\section{KunstKammeret}

\section{DET TYSKE SPROGOMRÅDE}

Kunstkamrene fik den mest rendyrkede form og den største udbredelse i det tyske sprogområde. Blandt de tidligste og bedst belyste var kunstkammeret i München ${ }^{3}$, hvor hertug Albrecht V 1563-67 lod en selvstændig bygning opføre, et fire-fløjet og tre-etages anlæg med stalde i stueetagen. I 1565 udgav hertugens rådgiver, lægen Samuel Quiccheberg, tillige det først kendte teoretiske skrift nord for Alperne om indretning af museer, "Inscriptiones vel tituli theatri amplissimi". Quicchebergs forbillede var florentineren Giulio $\mathrm{Ca}$ millos "Idea del Teatro" fra 1550, der videreførte den katolske kirkes helhedssyn, nu som nyplatonismens idé om verdensteatret, der lader mennesket ane det store i det små. I praksis fik Quicchebergs teori dog ikke den store indflydelse. For det første fik Kunstkammeret en særlig afdeling til genstande af ædelmetaller, bjergkrystal og halvædelsten, der blev samlet på skuebuffet' er i et hjørneværelse, hvis vægge prydedes af orientalske paradevåben. I umiddelbar tilknytning fandtes også samlingen af mønter. For det andet blev skulptursamlingen og biblioteket udskilt i en fælles bygning, Antiquarium, opført 1568-71. For det tredje båndlagde Albrecht $\mathrm{V}$ og hans hustru 17 pretiosa som "hus- og arveklenodier", der for altid skulle gå i arv til den ældste søn og ikke måtte sælges, pantsættes eller ændres. De blev opbevaret på slottet og kom til at danne grundstammen i det såkaldte kammergalleri, som kurfyrst Maximilian I lod indrette 1606-07. Hertil var der kun adgang med kurfyrstens personlige tilladelse, og her samledes nu mange af kunstkammerets udsøgte stykker, hvoraf flere blev båndlagt. I Maximilians sidste testamente fra 1641 nævnes kunstkammeret end ikke, fordi dets plads nu var overtaget af Skat- og kammergalleriet, der fra 1660'erne fik en fast plads i de fleste håndbøger om München.

Lignende tendenser ses hos Habsburgerne. Således fandtes en tilsvarende opsplitning af 
samlingerne hos ærkehertug Ferdinand II på Schloss Ambras i Tyrol. Også her var antiquarium og bibliotek udskilt. Kunstkammeret optog en af slottets fire fløje, våben de tre øvrige. De var opdelt $i$ et rustkammer, der havde afdelinger med turneringsudstyr, etnografica og tyrkiske våben, og i et heltekammer, der indeholdt kendte feltherrers buster og våben. Heltekammeret nød ærkehertugens særlige bevågenhed, hvorfor der udkom et trykt katalog 1601.

Antagelig var også kejser Rudolf II's kunstkammer i Prag et led i en større helhed. Det må huskes, at inventariet fra 1607-11, der kom for dagen i de Lichtensteinske samlinger 1947, kun omfatter godt halvdelen af kunstkammeret. Der er ikke fundet tilsvarende inventarier over Rudolf II's antikker og gemmer eller over hans skatkammer, skønt både kameer i pragtindfatninger og huskronen fra 1602, Rudolfs pièce de résistance er bevaret. Hvorom alt, 1612 flyttede kejser Mathias hovedstaden tilbage til Wien og lod et skat- og kunstkammer indrette på Hofburg, hvortil regalierne og udvalgte topstykker blev overført fra Prag. Senere tilkom båndlæggelser - som i München - og 1640-42 indrettedes et nyt galleri til denne samling, der nu kaldtes skatkammer. Pragten vistes i 13 skabe, hvoraf de sidste fem indeholdt bjergkrystal og halvædelsten samt - som klimaks - regalierne. Den samme stigningstakt sås på vinduesvæggens pilleborde, hvor f.eks. dynastiets stamklenodie penderede med regalierne. Endelig dækkedes endevæggen af et skab med tyrkiske våben. Som Rudolf Distelberger har konkluderet, forfulgte skatkammeret ikke et belærende eller æstetisk ideal. Målet var i stedet at guddommeliggøre kejseren ved at glorificere Habsburgerne som kristendommens forkæmpere mod Osmannerne. ${ }^{4}$
Lad os slutte med et blik på Sachsen, den 155 protestantiske modvægt til det katolske Bayern og den danske kongefamilies foretrukne ægteskabspartner med ialt fire giftermål 1548-1666. Kunstkammeret i Dresden havde til huse på slottet, hvor der også fandtes et skatkammer. Kunstkammeret blev grundlagt af kurfyrst August og talte ifølge inventariet fra 1587 knapt 10.000 genstande, hvoraf $75 \%$ havde teknisk karakter. Det afspejlede Sachsens førende rolle inden for europæisk bjergværks- og minedrift, men allerede Augusts søn, den ærgerrige Christian I, satsede anderledes. 1586-88 opførtes syd for slottet et rustkammer med stalde og rendebane, der havde forbillede i Philip II's i Madrid. Ud over våben og ridetøjer fandtes her klæder og etnografica, og rummene var udstyret med et anegalleri og med skænkeborde til skuesølv fra skatkammeret. I forsættelse heraf påbegyndtes i parken et lysthus med en grottesal, der skulle beklædes med sachsisk halvædelsten og tjene til udstilling af bjergkrystal. Dette lysthus blev aldrig fuldført, men følgen blev, at kunstkammeret først fik en større tilgang af artificialier i 1650 'erne. ${ }^{5}$

I et tilbageblik 1550-1650 fremstår udviklingen hos de førende hoffer i det tyske sprogområde som dobbeltsporet. På den ene side indførte kunstkamrene krav om viden og klassifikation i en verden præget af oversøisk ekspansion. På den anden side endte de bedste stykker hurtigt i skatkamrene. Måske var den væsentligste konsekvens en stigning $\mathrm{i}$ kunstnerisk udtryk og kostbarhed. For som bibelhumanismen lærte, har Herren udvalgt mennesket og givet det fornuftens lys. Og hvormed bedre ære sin Skaber end ved at forvandle naturalie til artefakt? Forbundet hermed var elementet af recreatio, fyrstens afslapning og eftertanke, enten ved drejebænken eller som 
JøRGEN HEIN

156 blot og bar samlerglæde. I baggrunden står Baldasare Castigliones ideal af hofmand, amatør og kender, der skal kunne konversere frit og utvungent om alt uden at lade sig tynge af fagmandens lærdom.

\section{Kongelige SAMLINGER I DANMARK I $523-\mathrm{I} 648$}

I 1523 tog Christian II de første Oldenborgeres regalier og pretiosa med i eksil. Efter reformationen blev regalier og skuesølv opbevaret i hvælvingen på Københavns Slot, mens kongens våben havde plads i flere rustkamre. I 1597 rejste Christian IV incognito til Dresden, hvor han beså rustkammeret, som han roste for dets gode orden. I 1598 startedes opførelsen afTøjhuset i København, hvor rustkamrene blev samlet og fortegnet i et særskilt inventarium, og 1599-1601 lod kongen et lysthus opføre i parken ved Frederiksborg slot. Det var Sparepenge, der med manieristisk ironi blev usædvanlig pragtfuldt udstyret. Sparepenge blev nedrevet 1720 , men to malerier viser dets ydre (fig. 1). Det havde en kælder, der tjente som stald, og to etager. Der findes intet inventarium. Vort kendskab skyldes dels tre rejseberetninger $(1617,1623$, 1642), dels tre bygningssyn, der kun anfører rummenes antal og navne $(1641,1645$, 1648). Den udførligste beskrivelse stammer fra 1623 og skyldes prins Christian af Anhalt. Hans omvisning startede i rustkammeret, der omfattede flere rum og indeholdt skyde- og blankvåben samt sadeltøjer. Særskilt bemærkede han sadelkammeret, hvor han især fremhæver en ungarnsk sadel med turkiser og Christian IV's ædelstensbesatte ridetøj med tilhørende kårde. Ligeledes nævner han en moskovitisk rustning, en gave fra zaren 1622. Dernæst et kombinationsvåben med kårde og gevær. Til sidst noteres en større mængde fjer, lanser og andre turneringsredskaber. Efter rustkammeret så prinsen spisesalen, der havde malerier i loftet, en skænk med 120 bægre, som Christian IV havde vundet i ringridning samt en model af et bjergværk. Til sidst omtaler prinsen musikanterrummet i stueetagen, hvorfra lyden via rør i vægge og loft kunne stige op i spisesalen. ${ }^{6}$

Prinsen af Anhalts omvisning viser Sparepenge som en officiel skuesamling. Et rustkammer, der forenede paradevåben med tekniske nyskabelser og etnografica, antagelig primært arvestykker og gaver. Dernæst intime repræsentationslokaler, hvor turneringspræmier fremhævede værtens ridderlige færdigheder, mens bjergværket kunne lede samtalen hen på de norske fjelde, hvor der netop $1623 \mathrm{blev}$ fundet sølv, alt imens det kongelige kapel, et af Europas bedste, fornøjede øret med liflige toner fra Musikanterstuen. Sparepenges våben skulle repræsentere og var ikke indsamlet med et encyclopædisk sigte. Da Sparepenge var Christian IV's eneste forsøg som samler, må man slutte, at denne aktivitet lå hans praktiske og resultatorienterede indstilling fjernt.

Det forklarer måske, at Christian IV gav sin ældste søn, den udvalgte prins Christian, råderet over Sparepenge, da han ægtede Magdalena Sibylla af Sachsen 1634. Berøvet politisk indflydelse fik tronfølgerparret en vis rolle som kulturmæcéner. De dyrkede musik og ballet og købte raderinger af Jordaens og Tenniers, Rubens og Rembrandt. ${ }^{7}$ I 1637 tilbød en kunsthandler tegninger til "Prinsens Kunstkammer", og i Sparepenges bygningssyn fra 1640'erne omtales musikanterstuen som kunstkammer. Det kan dog ikke have været særligt righoldigt, for tronfølgerparrets økonomi var elendig og der kendes kun en- 


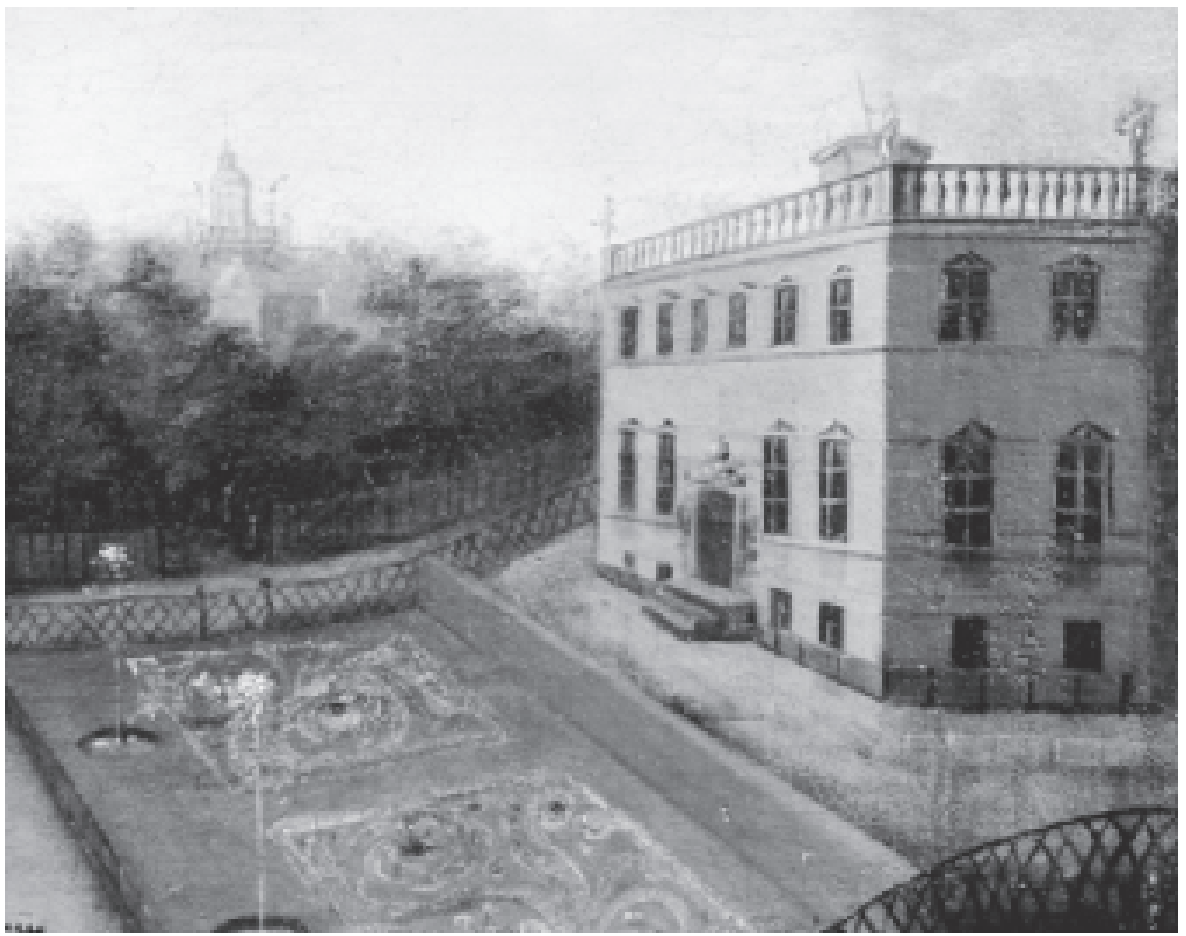

Fig. 1. Sparepenge. Detalje af anonymt maleri af Frederiksborgs Slot fra ca 1690. Det Nationalhistoriske Museum på Frederiksborg, inv. nr A 851. Foto: Hans Pedersen.

kelte anskaffelser. ${ }^{8}$ Kunstkammeret indgik da heller ikke i den officielle rundvisning 1642 , hvor gæsten i stedet fremhæver ridetøjerne, nu med ændringer udført til tronfølgerparrets bryllup 1634. Efter den udvalgte prins' død 1647 overlod Christian IV Sparepenge til hans yngre broder Frederik. Målet var at presse adelen til at vælge ham som tronfølger, og som konge lod Frederik III tilsyneladende Sparepenges kostbarheder forblive intakt, i al fald omtales de endnu i Jens Lauridsøns Wolfs Danmarksbeskrivelse fra 1654. Tillige blev der indrettet et værksted, hvor Peter Kalthoff fremstillede kunstbøsser. Først 1658, da Karl X Gustaf af Sverige førte sin hær over de til- frosne bælter og hastigt nærmede sig Frederiksborg, førtes Sparepenges kostbarheder til København.

\section{FREDERIK III'S SAMLINGER}

Sparepenges fortsatte eksistens har interesse, fordi Frederik III - samleren og kenderen blandt danske konger - primært huskes som grundlægger af Kunstkammeret. Dette synspunkt er imidlertid for snævert, også Det kongelige bibliotek og Rosenborg hører med $i$ helheden. Lad os derfor betragte trekløveret i den nævnte rækkefølge.

Kunstkammeret nævnes første gang 1650 
158 og lå i fortsættelse af kongens gemakker på Københavns Slot. Håndværkerregninger fra 1653 viser, at det nu omfattede flere rum, og hovedforøgelsen kom 1655 med købet af lægen Ole Worms kunstkammer, der talte 1663 numre, fortrinsvis naturalier. Kunstkammerets ældste inventarium stammer fra 1674 og viser en inddeling i otte tematiske rum eller kamre. Som helhed var samlingen præget af naturalier, mens kunsthåndværk var forholdsvist beskedent repræsenteret og især udmærkede sig ved drejede og skårne arbejder i organiske materialer. Også beholdningen af kunst synes sparsom, sikkert fordi mange skulpturer og malerier udsmykkede de kongelige slotte. Efter alt at dømme afspejler 1674 inventariet situationen ved Frederik III's død 1670, idet Christian V, der ikke delte sin lærde faders interesser, stort set standsede nyanskaffelser.

Medvirkende var også pladsmangel, for i 1650'erne var Frederik III begyndt at samle et bibliotek, og efter enevældens indførelse 1660 eksploderede tilgangen, alene 1662-65 tilkom henved 15.000 bind. I 1665 startede Frederik III derfor opførelsen af en ny treetages bygning over for Københavns Slot. Stue-etagen blev overladt til Tøjhuset, 1. etage til Det kongelige Bibliotek og 2. etage til Kunstkammeret. Biblioteket, hvis sal havde forbillede i kardinal Mazarins i Paris, blev opstillet umiddelbart efter bygningens fuldførelse $1673 .{ }^{9}$ Derimod kom indretningen af Kunstkammerets rum til at strække sig ind i 1680 'erne. Denne forsinkelse skyldtes utvivlsomt, at Frederik III døde 1670, før byggeriet var færdigt. Det bør derfor fremhæves, at vi ikke ved, om det var hans hensigt at forene kongehusets samlinger i den nye bygning. ${ }^{10}$

Spørgsmålet rejses, fordi Frederik III i 1660 'erne desuden begyndte at modernisere og at samle på Rosenborg. Grundstammen var Sparepenges kostbarheder, hvoraf hovedparten efter freden 1660 fik plads i to nyindrettede rustkamre i Store Tårn, hvortil kongen selv havde nøglen. I 1665-66 fulgte en opdeling i brugsvåben og i teknisk avancerede "kunstbøsser". Omtrent samtidig kan en lignende udvikling påvises for pretiosa og kunsthåndværk. Grundlaget er nyfundne arkivalier, dels regninger fra håndværkere, dels rejseberetninger $(1662,1668,1670)$ samt ceremonimesterens protokol 1661-1671. De retter opmærksomheden mod 1. salens nordøstre tårnkammer, der fik en dekoration af lakerede kineserier 1665. I dette "Intianske" Kabinet gav Frederik III ialt 8 private audienser, hvorfor ambassadørerne især færdedes i 1. etagens nordlige halvdel. Og her nævner rejseberetningerne kunstværker og skabe med rariteter, primært det ædelstensbesatte ridetøj, nu udstillet på en udstoppet hest. Tillige f.eks. en statuette af kejser Leopold I, skåret i ét stykke stål af Gottfried Leygebe og indkøbt i Nürnberg 1665, og voksbuster af Ludvig XIV, hans hustru og elskerinde, pousseret af Antoine Benoist i Paris 1668. I fortsættelse heraf igangsatte Frederik III en modernisering af flere af stue-etagens rum. I sine sidste år samlede Frederik III således både til Kunstkammeret på Københavns Slot og til Rosenborg.

\section{Christian v's og Frederik iv's SAMLINGER}

Hvis det var Frederik III's agt at forene kongehusets samlinger i den nye bygning, fulgte Christian V ikke hans intentioner. Tværtom lod han Rosenborg udbygge til et egentligt skatkammer. Her tillader pladsen kun at skitsere denne udvikling, der kan følges i glimt, atter takket være nyfundne rejseberetninger 
(1671, 1674, 1677, 1692). Allerede 1670 nævntes de tre sølvløver på Den lange Sal, i 1671 tilkom tronstolen af narhvaltand og 1677 Rubens kendte maleri af Salomons Dom. Dermed havde enevoldskongens tronrum fået bibelsk symbolik, og på 1. salen omtaltes tillige guldhornet og to kabinetter med malerier. I 1681 indrettedes slotskælderen til gehejmearkivet fra Københavns Slot, og samtidig fulgte antagelig både regalierne og samlingen af guldmønter, hvis ældste inventarium blev udfærdiget netop 1681. Få år senere lod Christian V sine sejre forevige i 12 gobeliner til Den lange Sal, og 1686 tilgik topstykkerne fra det rige bo efter enkedronning Sophie Amalie. I 1692 nævnes for første gang såvel Regaliekammeret som et nyt rustkammer til Christian V's egne våben og til ridetøjer i slottets portbygning. Slutstenen på denne udvikling var Rosenborgs ældste inventarium fra 1696, der er det eneste, som både

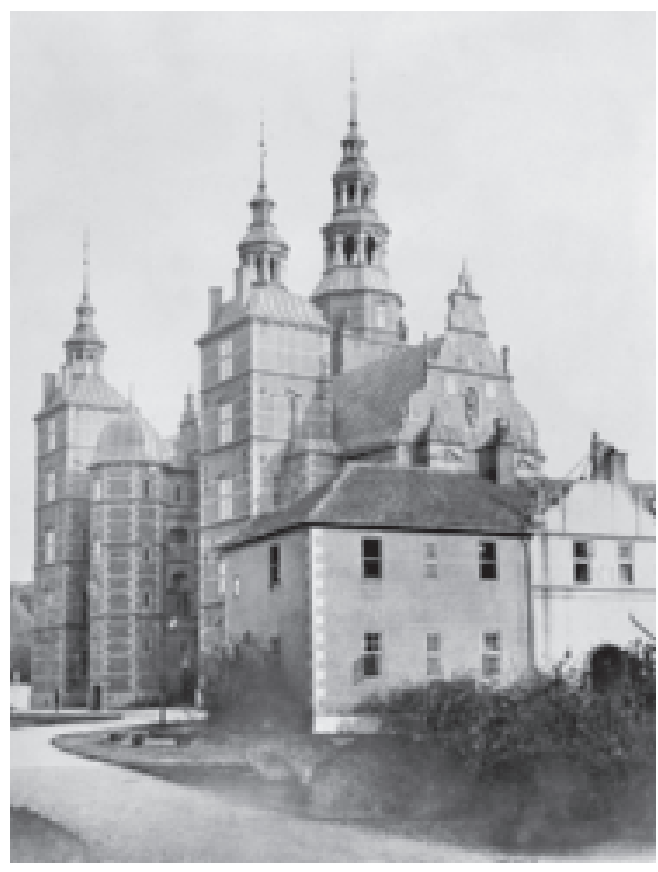

Fig. 2. Rosenborg, exterior og plan.

Rum 21: Den lange Sal med tronstol og solvlover foran v. gavl. Rum 24:

Regaliekammeret med Gronne Kabinet t.h. Rum 22: Glaskabinettet. Rum 23:

Porcelanskabinettet.

I de tre overste etager af Store Tårn:

Vabenkamre. I portbygningen foran h. gavl:

Sadel-og våbenkamre.

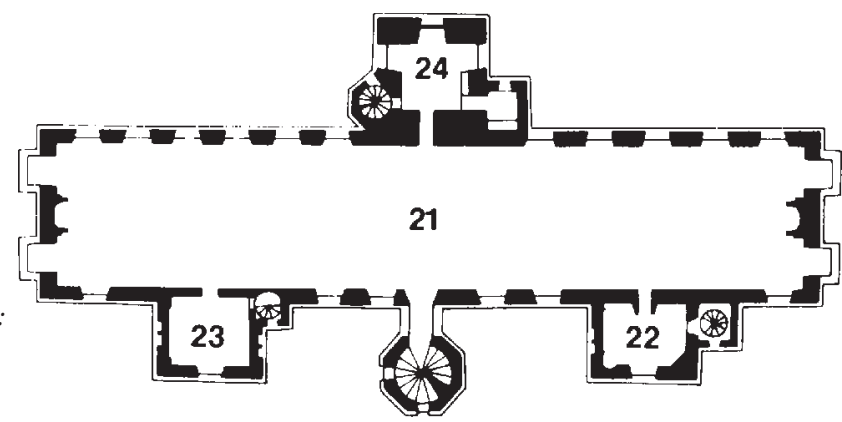

Fig. 3. Grundplan af Kunstkammeret.

Hovalergaarder.

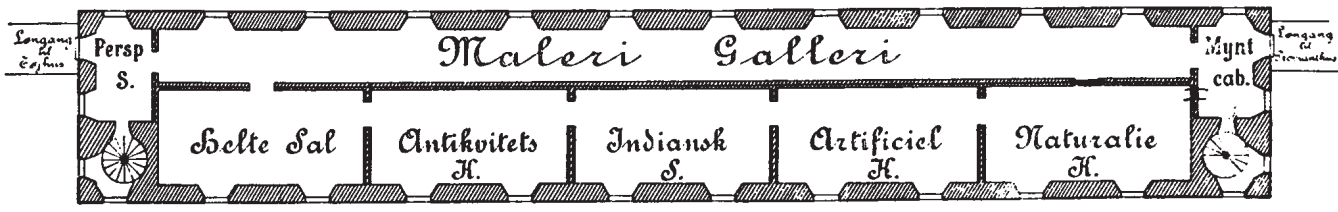


160 omfatter murskabene med regalierne hvortil kongen havde nøglen) og slottets øvrige indhold, der var slotsforvalterens ansvar. I Regaliekammeret anfører inventariet 174 pretiosa, i Grønne Kabinet 462 stykker kunsthåndværk, fortrinsvis af bjergkrystal og halvædelsten, i to kamre 167 miniaturer og 101 malerier samt i rustkamrene godt 900 våben foruden et antal ridetøjer (fig. 2).

I 1680'erne fuldførtes også Kunstkammerets opstilling i den nye bygning over for Københavns Slot (fig. 3). Det medførte en række tilgange fra de kongelige slotte, hvilket belyses af et nyt inventarium fra 1690, der tilkom som følge af et forvalterskifte. Ser vi på de med Rosenborg "konkurrerende" emneområder, anfører 1690 inventariet knapt 800 genstande under kunsthåndværk (2. Gemach/ Artificial-Kammer), 267 genstande under maleri/plastik (5-8. Gemach/Helden-, Galleri- Perspectiv- og Model-Kammeret) samt 119 våbn (4. Gemach/Antiquitet-Kammer). ${ }^{11}$ Allerede 1687 havde Christian V befalet Holger Jacobæus, læge og professor i historie og geografi, at udarbejde "en fuldkommen $\mathrm{Ca}$ talogum på Kunstkammeret”, der skulle oversættes til latin. Jacobæus afleverede sit manuskript 1689, men først 1696 udkom Museum Regium som et delvist illustreret katalog over et udvalg af Kunstkammerets genstande. I 1703 fulgte et supplement for tiden til Christian V's død 1699 og 1710 kom en forøget udgave, begge ved numismatikeren Johannes Laverentzen. De tre udgaver viser, hvad Christian V, Frederik IV og deres rådgivere, ønskede at præsentere for udlandet og afspejler samtidig deres bud på, hvad den dannede læser måtte forvente at finde.

I sin opbygning følger Museum Regium traditionen fra Ole Worms katalog i dens skelnen mellem naturalier og artificialier, dog med den forskel, at Museum Regium starter med mennesket og går baglæns i udvikling og kompleksitet og ender med sten og mineraler. Hvor Museum Wormianum kun havde anvendt knapt $12 \%$ af pladsen på artificialier, vægtede Museum Regium - som påpeget af både H. D. Schepelern og Flemming Steen Nielsen - langt mindre dækkende for Kunstkammerets bestand, idet naturalier er forholdsvist beskedent repræsenteret, mens artificialier, nordiske etnografica og især mønter og medailler optager hovedpladsen, også selvom guldmønterne, efter alt at dømme blev opbevaret på Rosenborg. ${ }^{12}$ Dette forhold ses allerede i 1696 udgaven, men forstærkes, således at mønter og medailler optager $60 \%$ af den trykte tekst i 1710. Samtidig udvides beskrivelsen af mange genstande, oftest med oplysninger af historisk karakter. ${ }^{13}$

Sluttelig - og væsentligt i nærværende sammenhæng - har 1710 udgaven under antikviteter et længere afsnit der henviser til Det kongelige Skatkammer på Rosenborg. ${ }^{14}$ Heri fremhæves først "de skønne rækker" af kameer og gemmer, dernæst de "gamle drikkekar" - skåle, fade og pokaler - af (bjerg)krystal og halvædelsten. Denne omtale må skyldes, at Museum Regiums udgivere har fundet det nødvendigt at give læseren en forklaring på, hvorfor Kunstkammerets bestand af artificialier i bjergkrystal og halvædelsten - renæssancens og manierismens genre par excellence - var beskeden.

Dermed udtrykker henvisningen en rollefordeling mellem de to samlinger. Spørger man, hvilke skillelinjer der lå til grund, er udgangspunktet Kunstkammerets til- og afgangslister, der er bevaret fra 1690 og følgelig tillader at følge bevægelserne mellem Kunstkammeret og Rosenborg. ${ }^{15}$ Interessant er især årene fra 1689-90, da Jacobæus afleverede sit 
manuskript og Kunstkammeret fik nyt inventarium, og frem til udarbejdelsen af Rosenborgs inventarium 1696. Betragter vi atter de "konkurrerende" emneområder, kunsthåndværk og maleri/plastik, ses en række afgange fra Rosenborg til Kunstkammeret. De er alle medtaget i Bente Gundestrups offentliggørelse af Kunstkammerets inventarium fra 1737 og forsynet med årstal, men ikke altid med afsender. Anonyme er således to afgange fra Rosenborg 1692 og 1695 af ialt 26 umonterede drejerarbejder - dåser, bægre og en enkelt stok. ${ }^{16}$ Til rest i Grønne Kabinet forblev kun 22 drejerarbejder, alle af elfenben og narhvaltand, hvoraf 12 var udgået i Rosenborgs næste inventarium 1718. Ser vi derimod på skairne arbejder af elfenben og narhvaltand, havde Grønne Kabinet hovedparten af pokaler, krus og bægre ${ }^{17}$, mens Kunstkammeret besad de fleste portrætmedailloner og relieffer. Ligeledes var genstande af andre organiske materialer som koral, næsehorn og træ, drejede eller skårne, stort set forbeholdt Kunstkammeret. Aforganiske materialer rummede Gronne Kabinet således primart elfenben og narhvaltand, fortrinsvis skärne pokaler, krus og bagre indfattet $i$ adelmetaller. ${ }^{18}$

Det modsatte billede møder os, hvis vi ser på mineraler, idet Kunstkammeret, fraregnet mineralprøver, imitationer af ædelsten og pietre dure indlægninger, kun havde 20 genstande af bjergkrystal og halvædelsten. ${ }^{19}$ Edle mineraler var klart reserveret Grønne Kabinet. Et forhold, der forstærkedes, da Kunstkammeret så sent som 1696 til Rosenborg afgav 39 kameer og gemmer ${ }^{20}$, knapt hele Artificialkammerets beholdning. ${ }^{21}$

Hertil kommer en anden forskel. I afgangene fra Rosenborg 1692 og 1695 indgik dels 8 elfenbensdåser, drejet af kronprins Frederik (IV) som nytårsgave til Christian V, dels et voksportræt, pousseret af kronprinsens halv161 broder, Christian Ulrik Gyldenløve. ${ }^{22}$ Antagelig afgav Rosenborg tillige Leonora Christina Ulfeldts kolorerede stik af Christian IV, som hun havde sendt Christian V med en bøn om frigivelse $1685 .{ }^{23}$ Endelig nævner Museum Regiums anden udgave fra 1710, at Frederik III's portræt af præsten i Jorck, der først nævnes på Kunstkammeret 1699, også kom fra Rosenborg. ${ }^{24}$ Kongelig "husflid" hørte hjemme på Kunstkammeret.

Skal man opsummere synes bevægelserne mellem Rosenborg og Kunstkammeret 169096 at have fulgt principper, hvorefter skårne og monterede elfenbener samt bjergkrystal og halvædelsten var forbeholdt skatkammeret (fig.4). Havde denne fordeling paralleller?

\section{TEORETISKE FORBILLEDER}

I løbet af 1600-tallet fremkaldte bl.a. den europæiske ekspansion og naturvidenskaberne en eksplosion af viden, der sprængte tanken om kunstkammerets universelle helhed og $\mathrm{i}$ stedet pegede mod specialsamlinger. ${ }^{25}$ Dermed fik forholdet mellem kunstkammer og skatkammer mindre interesse for den "museologiske" debat, hvorfor der her kun skal nævnes to bidrag, Johann Daniel Major's "Unvorgreiffliches Bedencken von Kunst- und Naturalien-Kammern insgemein" fra $1674^{26}$, og Leonhard Christoph Sturm's "RaritätenUnd-Naturalien-Kammern" fra 1707. ${ }^{27} \mathrm{~F}$ ælles er en historisk-filologisk gennemgang af benævnelserne for forskellige samlingstyper samt af begrebet "raritet", vel at mærke uden at der findes en entydig definition. ${ }^{28}$ Dernæst fastholdes en klassifikation af genstande efter materiale. Opstår der tvivl, bestemmer kunstkammerforvalteren, som Major og Sturm gør til en slags deus ex machina. Han bør derfor 
162 være lærd, ikke en "Schul Fuchsisch Gelehrte/oder Uhrmacher/Kunstdrechsler/oder welches noch ärger/Materialien-Krämer/Mahler/ Bildhauer/Kammer=Diener". Til gengæld bør forvalteren have hjælp af en håndværker.

De mange ligheder mellem Major og Sturm skjuler en både personlig og tidstypisk forskel $\mathrm{i}$ interesse. For Major, der var læge, stod naturalierne i centrum. Derimod havde Sturm, ingeniør og lærer ved det ridderlige akademi i Wolfenbüttel, betydelig interesse for kunst. Således giver Sturm såvel en definition på et skatkammer som en opregning af, hvad det bør indeholde. Hans definition fortjener at anføres:

Schatz=Kammern sind solche Oerter .../darinnen alles das jenige auffbehalten wird/was man aus den kostbahrsten Materien als Edelgestein/Perlen/Gold/Silber/ Perlenmutter/Elffenbein/raren und kostbahren Holz und Lackwerck u. s. w. durch Kunst verfertiget oder zusammen setzet. Daher man diese Dinge leicht von den jeningen unterscheiden kann/welche eigentlich in Kunst=Kammern gehören. Weil man hier mehr auff die Kostbarkeit der Materie als auf die Kunst siehet/ dorten mehr auff die Kunst/ja fast allein/ohne absonderliche Absicht auff die Materie, ohne so weit die Arbeit dadurch desto kunstreicher zu halten ist/weil die Materie schwer arbeiten lässet.

Kort sagt funkler skatkammerets genstande ved materialernes kostbarhed, mens kunstkammerets stykker kendetegnes ved deres kunstfærdige forarbejdning. Interessant er også skatkammerets indhold, der nuancerer forskellene. Først nævnes et kammer med kameer og gemmer, der ifølge Sturm er så tidskrævende for stenskæreren at udføre, at kun fyrster kan betale. For mindre bemidlede kan mønter og medailler udgøre en erstatning. Dernæst følger et kammer med skabe i japansk lakarbejde med drikkekar, toiletred- skaber, røgelseskar, blomstervaser og thetøj i guld og ædelsten, orientalsk lak og porcelæn. I det næste kammer kommer skabe og kabinetter af europæisk arbejde, hvori udstilles ædelsten og perler samt kunsthåndværk i bjergkrystal og halvædelsten, rav og elfenben samt endelig guld, sølv og ure, som vel og mærke glimrer ved både den kunstneriske udførelse og materialets kostbarhed. Denne kombination betegner de såkaldte mirabilia, hvor menneskelig snilde har forvandlet naturalier til artificialier. Et sidste kammer med paradevåben, militaria og ridetøjer afslutter skatkammeret. Fyrstelige drejerarbejder henregner Sturm derimod under kunstkammerets artificialier, idet fyrsten ikke er kunstner af profession. ${ }^{29}$

Snarere end nyskabende må Sturms synspunkter ses som en opsummering af eksisterende tendenser, der i 1690'erne også havde fundet anvendelse i København. Det gælder såvel fremhævelsen af elfenben, herunder fordelingen af drejede versus skårne og indfattede arbejder, som især af bjergkrystal og halvædelsten, der netop bygger på både materialernes og forarbejdningens kostbarhed. En parallel er også placeringen af fyrstelig husflid på Kunstkammeret.

Denne fordeling fører til spørgsmålet om klassifikation. Som det fremgår af fig. 4, var kriterierne i Grønne Kabinet primært genstandenes materiale og sekundært deres brug, hvilket gav en symmetrisk-dekorativ opstilling. Dog har forskellen til Kunstkammeret næppe været stor, for i 1690 var den skarpe opdeling efter materiale og teknik, der kendetegner de 18 grupper af artificialier i Kunstkammerets inventarium fra 1737, endnu ikke gennemført. I 1737 fordeltes de 18 grupperinger på 7 skabe samt en ophængning. I 1690 ses i stedet en ophængning samt 4 skabe, der 


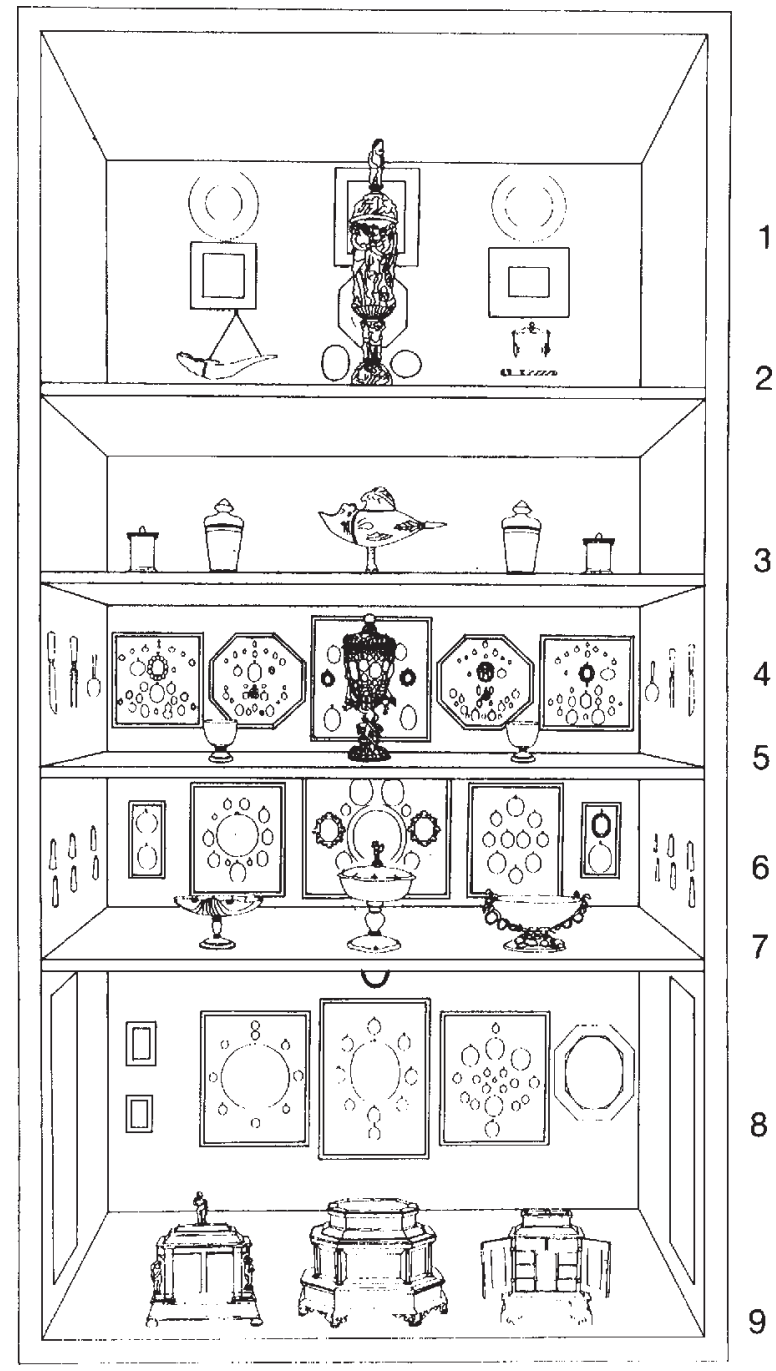

1

2

3

4

5

6

7

Fig. 4.

Vegskabet i Gronne Kabinet 1718.

8

1-2 Elfenben, narhvaltand.

3 Bjergkrystal.

4 Smykker, kameer og bestik.

5 Halvadelsten.

6 Miniatureportratter og bestik.

7 Halvadelsten.

98 Miniatureportratter og gemmer.

9 Elfenben. blander genstande af forskellige materialer og teknikker, således at de hyppigst forekommende går igen i samtlige skabe. Følgelig har udstillingen været anlagt efter symmetrisk-dekorative principper, der skabte ro i mangfoldigheden. ${ }^{30}$ Antagelig skyldtes den øgede sys- tematik i 1737 de tre udgaver af Museum Regium.

I valget af personale ses derimod en forskel. Sturms krav om, at kunstkammerforvalteren burde være lærd, blev fulgt til ca. 1710 , først af akademisk uddannede in- 
164 spektører og senere af Museum Regiums udgivere. Tilsvarende var den daglige leder håndværker, oftest kunstdrejer eller maler. ${ }^{31}$ Modsat startede Rosenborgs fire slotsforvaltere 1681-1781 alle som kongens livkarl, page eller kammertjener. Afgørende var ikke faglige kvalifikationer, men monarkens tillid. Også i tilgængelighed var der forskel. Mens både Kunstkammeret og Rosenborgs gemakker var åbne for omvisninger mod betaling, krævede det "besynderlig" tilladelse at se regalierne frem til 1922.

I et tilbageblik afspejler de mange initiativer og flytninger i 1680'erne og 1690'erne nederlaget i Den skånske Krig, der forpligtede fremtiden til revanche mod Sverige. Dermed forsvandt også de økonomiske muligheder for at opføre en ny residens, og i stedet søgte den unge enevælde nu prestige ved at ordne de kongelige samlinger. Dels ved færdigindretningen af Frederik III's "kulturhus" og udgivelsen af Museum Regium, dels ved anlæggelsen af et skatkammer og af nye rustkamre på Rosenborg. For kunsthåndværk blev udfaldet den ovennævnte fordelingsnøgle: Skatkammeret fik fortrinsret til skåret og monteret elfenben, bjergkrystal og halvædelsten; Kunstkammeret til drejet elfenben og øvrige organiske materialer.

\section{Perspektiver}

Disse skillelinjer holdt sig stort set til grundlæggelsen af dansk museumsvæsen i 1820'rne. Det kan undre, fordi den lange fred efter 1720 og opførelsen af Christiansborg Slot 1740 skabte nye muligheder. Lad os derfor kort skitsere udviklingen, der synes tre-delt.

I 1713 erobrede Frederik IV Slesvig-Holsten-Gottorp og lod hertugernes private samling overføre til Rosenborg. Her kom forde- lingsnøglen i brug. Bjergkrystal, halvædelsten og skårne elfenbener, henved 180 genstande, tilgik Grønne Kabinet. Drejet elfenben, andre organiske materialer og det øvrige, mindst 235 stykker, indgik derimod i et privat kunstkammer, som Frederik IV lod indrette i Vinterstuen. ${ }^{32}$ Omtrent samtidig blev de to øvrige tårnrum på riddersalsetagen, modsat Regaliekammeret og Grønne Kabinet (fig. 2), indrettet som glas- og porcelænskabinetter. Det illustrerer Frederik IV's prioritering af skatkammersamlingen frem for Kunstkammeret.

I 1740'rne lod Frederik V sin bedstefaders private kunstkammer i Vinterstuen opløse. Han udtog nogle af genstandene til sin egen samling af pretiosa og kunsthåndværk på Christiansborg, overlod andre til en lignende samling, der blev båndlagt til dronningens brug, og sendte resten til Kunstkammeret. ${ }^{33}$ Efter Frederik V's død 1766 fulgte en lignende deling af hans samling mellem Rosenborg og Kunstkammeret Det gentog sig, da det, der blev reddet ved Christiansborg Slots brand 1794, blev fordelt $1797 .^{34}$

En tilsvarende fordeling ses tillige ved tilgangene fra dødsboerne efter samtlige enkedronninger og ugifte prinsesser $(1714,1735$, 1743, 1770, 1783). Dog efterlod enkedronning Sophie Magdalene sig så stort et bo, at megen bjergkrystal og halvædelsten af beskeden kvalitet tilgik Kunstkammeret. ${ }^{35}$

Bruddet kom med oprettelsen af en specialsamling, Den kongelige Mønt- \& Medaillesamling, 1781. I samlingen, der fik lokaler på Rosenborgs første etage, forenedes guldmønterne fra Regaliekammeret med Kunstkammerets store bestand. Ifølge kommissoriet skulle den nye samling imidlertid også omfatte "antiquer" og "udskaarne Steene", og 1785 afgav Grønne Kabinet sine kameer og 
gemmer, ialt 196 genstande. Glyptik havde imidlertid ikke numismatikernes interesse, og allerede 1791 blev kameer og gemmer sendt videre. Dog ikke retur til Grønne Kabinet, men til Kunstkammeret. ${ }^{36}$ Manden bag denne afgørelse var Johan Bülow, kronprins Frederik (VI)'s magtfulde hofmarskal, der netop havde ladet sig udnævne til chef for Kunstkammeret. Samtidig udvirkede Bülow en fuldmagt til at måtte "udsøge tienlige Stykker" på de kongelige slotte til Kunstkammeret, og i februar 1793 foreslog han at overføre regalierne til Christiansborg og Rosenborgs øvrige samlinger til Kunstkammeret. Omfanget af Bülows planer og hans politiske opbakning er ukendt, og hans bestræbelser løb ud i sandet, da han faldt i unåde sommeren 1793. ${ }^{37}$ Bülows forslag viser imidlertid, at enevælden, blot få år efter Den franske Revolution, var bevidst om behovet for en nyordning af de kongelige samlinger, idet museumstanken nu var blevet spydspids i aristokratiets og borgerskabets kamp om politisk indflydelse og kulturel identitet. I stedet kom Englandskrigene og tabet af Norge til at betyde en udsættelse til 1820'erne, da Kunstkammeret blev opløst i specialmuseer og tanken om at gøre Rosenborg til et museum for kongehuset tog form.

\section{Nationalmuseet og ROSENBorg}

Grundlæggelsen af dansk museumsvæsen er behandlet andetsteds, hvorfor der her kun skal fremdrages to aspekter. I 1822 tilstillede lederen, overhofmarskal Adam Wilhelm Hauch, den til formålet nedsatte kommission et oplæg. Heri spurgte han

om ikke alle de af Guld og Sølv forarbejdede Sager, som nu befindes paa Kunstkammeret, i Forening med de derværende ægte og andre slebne Stene og Agather, forarbejdede som Skaale og Vaser m. m. [de ovennæv165 nte kameer og gemmer], rigtigst bleve at forene med de lignende Ting, som allerede befindes paa Rosenborg, for samme Steds at opbevares og der at udgiøre en Samling for sig selv.

Til gengæld skulle Rosenborg afgive til Kunstkammeret alle de Ting, som egentlig er Kunstsager, de i Elfenben udskaarne Basrelieffer o.s.v. saa vel som alle Oldsager.

Samlingen paa Kunstkammeret og paa Rosenborg skulde efter min Meening med eet Ord bestemmes og skiælnes fra hinanden derved, at alt det, som nu haves i begge Samlingerne og som kan henregnes til egentlige Kunstgienstande, blive at opbevare paa Kunstkammeret, hvorimod alle de Sager, der mere have deres Værdi fra de Materialer eller de Materier, hvoraf de vare forfærdigede, end fra Kunstsiden, skulde opbevares paa Rosenborg Slot. ${ }^{38}$

Hauchs udgangspunkt var således den "gamle" fordelingsnøgle, men udfaldet blev det modsatte. I 1823-24 afgav Rosenborg hovedparten af elfenben, bjergkrystal og halvædelsten, men fik til gengæld flere hundrede genstande med kongelig tilknytning fra Kunstkammeret, herunder husflidsstykkerne. Det var med denne bestand af kunsthåndværk, suppleret af mindre arbejder fra Regaliekammeret og af Glaskammeret, at Rosenborg åbnede som museum 1838. Da udstillingen bestod af interiører, der følger kongerækken, kom forøgelserne væsentligst til at bestå af Frederik VI's og Christian VIII's personlige effekter.

Modsat fik Kunstkammerets afløser, Det kongelige Kunstmuseum, den største og fineste koncentration af kunsthåndværk, der er set i Danmark. Det afspejledes i nye inventarier, hvis beskrivelser formidlede samtidens faglige viden om genstandene i modsætning til tidligere tiders knappe karakteristik, hvis formål blot havde været genkendelighed. Den- 
166 ne tendens styrkedes i 1840'rne, da arkæologen C.J. Thomsen nyordnede samlingen til "Museet for Skulptur og Kunstflid". Resultatet blev en forløber for de senere kunstindustrimuseer, der viste udviklingsrækker inden for europæisk kunsthåndværk, omend i den vante symmetrisk-dekorative opstilling. ${ }^{39}$ Dermed havde dansk guldalder vist internationalt niveau, men genstandenes vandringer var ikke slut. Et sidste led må med for at belyse senere begrebsforvirring.

Baggrunden var enevældens afskaffelse og folkestyrets indførelse 1848 samtidig som de nationale spændinger mellem dansk og tysk blev udløst, først i det slevig-holstenske oprør 1848, der endte med dansk sejr, dernæst i krigen med Preussen og Østrig, som førte til hertugdømmernes afståelse 1864. I samme periode havde C.J. Thomsen begyndt opbygningen af det senere Nationalmuseum i Prinsens Palæ-Etnografisk Samling åbnede 1846, Antikcabinettet 1851 og Oldnordisk Museum 1856. Imidlertid sparede det nye folkestyre på kulturen. Til gengæld skulle en række af de kongelige slotte og deres indbo nu overgå til statsejendom, og ved den barnløse Frederik VII's død, ville tronen, meget mod hans vilje, overgå til den Glücksborgske sidegren, der havde ry som tyskvenlig og udemokratisk, hvorfor der ikke var nogen til at sikre dens fremtidige interesser.

Parallelt hermed var Rosenborg blevet et fideicommis, "udeleligt og arveligt fra konge til konge" 1854, og 1858 blev arkæologen J.J.A. Worsaae, der stod i modsætning til C.J. Thomsen men nød amatørarkæologen Frederik VII's gunst, udnævnt til leder. Ifølge Worsaaes erindringer stod hans mål klare fra starten. Dansk museumsvæsen burde afspejle civilisationens fremadskriden: Etnografisk Samling skulle vise fremmede folkeslag,
Antikcabinettet den klassiske oldtid og et kommende museum for maleri og skulptur den senere udvikling. Sideløbende skulle Danmarks kulturhistorie deles mellem $\mathrm{Mu}$ seet for Nordisk Oldtid frem til Christian IV's tronbestigelse 1588, hvor Rosenborg skulle tage over, eventuelt fulgt af et fremtidigt museum for folkestyrets tidsalder efter 1848. I forbindelse hermed foreslog Worsaae bygningen af et nyt nationalmuseum på Livgardens eksercerplads, i umiddelbar tilknytning til Rosenborg, således at slottet ville blive "juvelen i Danmmarks krone".

Afgørende for Worsaaes planer blev Frederiksborg Slots brand 1859, der føltes som en national ulykke. Før asken var kold, udvirkedes Worsaae et kongeligt reskript, der gav ham ret til at udtage til Rosenborg fra samtlige kongelige slotte - en klar parallel til Johans Bülows tilladelse 1791. ${ }^{40}$ Følgen blev store overførsler af møbler og malerier. Dernæst kom nederlaget i krigen 1864, som medførte en konservativ reaktion, og 1866 blev Worsaae, i forståelse med det nye kongehus og mod C.J. Thomsens indstilling, leder af Etnografisk Samling og Museet for Nordiske Oldsager. Året efter fulgte nedlæggelsen af Museet for Skulptur og Kunstflid, og ved den følgende deling med Oldnordisk Museum fik Rosenborg løvens part, over 650 genstande. Ikke kun returneredes hovedparten af den bjergkrystal og halvædelsten, der var blevet afgivet fra Grønne Kabinet 1823-24. Nu fulgte det bedste af Kunstkammerets drejerarbejder, relieffer og statuetter, uanset organisk materiale. ${ }^{41}$ Ved at definere Rosenborg som kulturhistorisk nationalmuseum gjorde Worsaae skatkammeret til arvtager af Kunstkammerets kunsthåndværk. Og da regalierne forsat var skjult bag lås og slå og bjergkrystal og halvædelsten blandedes med Kunstkammerets 
genstande, skabtes en overbevisende helhed. For udenlandske fagfolk blev Worsaaes Rosenborg "ein vortreffliches Bild einer alten Kunstkammer”. Karakteristikken, der skyldes den tyske kunsthistoriker Julius von Schlosser, blev fremsat i hans bestseller "Die Kunst und Wunderkammern der Spätrenaissance" fra 1908. Billedet dækker hvad Schlosser så, men ikke historien forud. Det bliver opgaven for den kommende katalog over Rosenborgs skatkammersamling.

\section{SUMMARY}

Status versus Learning? Schatzkammer or Kunstkammer? In the 1660s Danish absolutism built up a treasure collection at Rosenborg Castle and a Kunstkammer opposite Copenhagen Castle. both of which contained applied art. It is the aim of this paper to trace this overlapping and to show that around 1690 principles were established for a division of objects that resulted in the two institutions becoming mutually supplementary. In other words the subject is royal heritage and royal collecting 1520-1920.

A comparison calls for definitions. A 'treasure collection' refers to an accumulation of valuable objects that is arranged with pomp and splendour. Three characteristics should be highlighted: the Prince or his official has the key to the collec;tion, the objects are partially entailed as inalienable property, and viewing requires the permission of the sovereign. A 'Kunstkammer' in this context means a collection of objects that are classified and displayed according to distinct principles which reflect human knowledge and theories about the surrounding world. Consequently the treasury represents and can provide, in time of emergency, a capital reserve, whereas the fundamental concept of the Kunstkammer is the structuring and imparting of knowledge as expressed in the publication of catalogues.

The Kunstkammer achieved its purest form and its most widespread distribution in the German-speaking 167 area. It has to be stressed, however, that most were only parts of a system of interdependent collections and that in many cases the Kunstkammer existed for only a short time. From around 1600 the most significant of them gave up their best objects to treasure collections as happened in Munich and in Vienna. Expressed in very simplified terms, the treasure collection underwent a Renaissance in the Baroque period. This development also had consequences for Denmark. Christian IV (1588-1648) had a pavilion built in the grounds of Frederiksborg Palace between 1599-1601. It was named Sparepenge and became an official display-collection, an armoury combining ornate weapons and technical innovations with tournament equipment and ethnographica. In 1634 the king handed over Sparepenge to the Crown Prince, and in the 1640s one of the rooms is referred to as a Kunstkammer, however sparingly furnished. In 1647 on the death of the Crown Prince, Christian IV defined Sparepenge as inalienable "Crown treasure" and had it transferred to the future Frederik III (1648-70). Apparently the new king, who founded the Kunstkamrner at Copenhagen Castle in 1650, left Sparepenge intact, but on the eve of the Swedish invasion in 1658 Sparepenge's treasures were rescued and taken to Rosenborg, where they formed the core of a new collection. When Frederik III started the construction of a new building to house the Kunstkammer, library and armoury in 1665, he collected applied art for both the Kunstkammer and for Rosenborg.

If it had been Frederik III's intention to unite all royal collections in the new building, Christian V (1670-99) extended Rosenborg into a genuine treasure collection including the regalia. When the Kunstkammer finally moved into the new building, a dividing line was established, as proved by the accession and de-accession lists of the Kunstkarnmer 1689-1696. Roughly speaking vessels of rock crystal and hardstones as well as cameos and intaglios were reserved for Rosenborg. Ivory and narwhal tusk, mostly in the form of carved goblets, tankards and beakers with moun- 
168 tings of precious metal were also the preserve of Rosenborg, while turned objects and works of other organic materials were placed in the Kunstkamrner. Finally, royal handicraft belonged in the Kunstkamrner.

In retrospect three things should be noted. First that these dividing lines paralleled the theoretical model put forward by Leonhard Christoph Sturm in his treatise on "Raritäten-UndNaturalien-Kammern" from 1707. Secondly that they remained virtually intact until 1785 , when the cameos and intaglios were transferred to the new Royal Collection of Coins and Medals. Thirdly that they also formed the basis for the initial plans when the Kunstkammer was dissolved in the 1820s and the early Danish Museums established. The outcome, however, was not to establish clear divisions for distribution, but quite the opposite.

Between 1823-24 Rosenborg handed over most of its ivory, rock crystal and hardstones, but received in turn several hundred objects with royal associations from the Kunstkammer, including the royal handicraft items. They formed the bulk of the centents when Rosenborg opened as a museum belonging to the royal family in 1838. In contrast the successor to the Kunstkammer, the Royal Art Museum, held the largest and finest concentration of applied art works ever seen in Denmark. In 1864 Denmark's defeat to Bismark's Prussia was followed by a political reaction that heralded new museum plans. Now Rosenborg was defined as a national museum for the period 1588-1848 and the Royal Art Museum was closed down. As a consequence Rosenborg received not only most of the rock crystal and hardstone which had been handed ovcr in 182324, but also the best of the Kunstkammer's tumed works, reliefs and statuettes, regardless of whether or not they were of organic material. As the regalia were still unaccessible to the public, the ensuing mixture of objects may explain the description of Rosenborg as "ein vortreffliches Bild einer alten Kunstkammer", which was put forward by the German art historian Julius von Schlosser in his bestseller "Die Kunst und Wunderkammern der Spätrenaissance" from 1908.

\section{Noter}

- Denne artikel er en bearbejdet udgave af forelæsning afholdt på Museumshøjskolens museologiske forelæsninger tirsdag den 7. marts 2000.

1. Gundestrup, Bente (red.): Det kongelige danske Kunstkammer 1737 / The Royal Danish Kunstkammer 1737, I-II, 1991.

2. Boesen, Gudmund: Danmarks Riges Regalier, 1986 og Royal Arms at Rosenborg, I-II, 1956. Hein, Jørgen: ”Das Grüne Kabinett im Schloss Rosenborg - Schatzkammer oder RaritätenKabinett?" i Andreas Grote: Macrocosmos in Microcosmo. Zur Geschichte des Sammelns 1450-1850, Opladen 1994, 323-337, og Krise og Kroning. Frederik III's regalier 1648, 1998.

3. Seelig, Lorenz: "Die Münchener Kunstkammer". Jahrbuch der bayerischen Denkmalpflege, Band 40, München 1990, 101-103.

4. Scheicher, Elisabeth og Distelberger, Rudolf $\mathrm{i}$ Impey, Oliver \& MacGregor, Arthur (red.): The Origins of Museums, Oxford 1985, 29-38 og 3946. Beket Bukovinská i Eliska Fuciková \& al.: Rudolf II and Prague, London 1997, 199-208.

5. Syndram, Dirk: Die Schatzkammer August des Starken, Leipzig 1999, 22-39, og Hoyer, Eva Maria: Sächsischer Serpentin, Leipzig 1995, $71-$ 72, 90-91.

6. Krause, G. (udg): Tagebuch Christian des Jüngeren Fürst zu Anhalt, Leipzig 1858, 95-101.

7. Otto Andrup: "Kunstnere ved den udvalgte Prins Christians Hof", Kunstmuseets Aarsskrift, 1920, 96-110.

8. Victor Hermansen: "Den udvalgte Prins og Rariteterne. Et Stykke Museumshistorie", Kulturminder, Ny rk., III, 1960, 16-44.

9. Ilsøe, Harald: Det kongelige Bibliotek i støbeskeen, 1, 1999, 35, 190. Helge Gamrath i Hvidt, Kristian, Ellehøj, Svend \& Norn, Otto: Christiansborg slot, I, 1975, 126-130.

10. Hermansen, Victor: "Fra Kunstkammer til Antik-Cabinet", i Antikcabinettet, 1951, 29. 
11. Inv. over Det kgl. Kunst og Raritet Kammer 1690-98 (afskrift ved John Bundgaard Rasmussen 1985), fol. 46-72, 343-357, 92 nr. 73 - 97 nr. 150.

12. Jørgen Steen: Den kongelige Mønt- og Medaillesamling 1781-1981, 14-18.

13. Schepelern, H. D.: "Natural Philosophers and Princely Collectors: Worm, Paludanus and the Gottorp and Copenhagen Collections" i Impey 1985, 121-127. Flemming Steen Nielsen: Fra fyrsteligt raritetskabinet til offentligt museum. En undersogelse af museumsarbejdet og dets rolle i kulturkampen i Danmark under enevalden. Specialeopgave ved Københavns Universitet 1988, 26-31.

14. Part III, Section II, No. 58.

15. NM Grønne arkivkasser nr. 5: Afskrift af Inv. 1690 og Tilgangsliste 1691-1733 sikkert udført til Brug ved Aflev. 1737.

16. NM Grønne arkivkasser nr. 18: Afskrift af Grodtschillings Manuale 1690 - c. 1737. Gundestrup 1991 I 759/225-226, 761/254-263; 766/328-335, 757/352; 771/406, 771/421-423.

17. Af de 10 krus og pokaler i Kunstkammerets 1737 inventarium, tilgik 5 så sent som 1735, antagelig fra prinsesse Sophie Hedevigs bo jf. Gundestrup 1991, I, 756/170-171, 757/180, 757/184 (fejlidentifikation)-185 og 755/163-166, 755/168.

18. Undtagelser er 2 bægre af hvalros, 3 figurer af koral, 1 kårdefæste af næsehorn, 1 statuette og 1 relief af buksbom.

19. 7 stykker kirkeinventar af bjergkrystal jf. Gundestrup 1991, II, 827/53, 827/72, 830/91, 830/ 98-99 og 12 genstande af halvædelsten jf. samme I, 743/13, 742/52, 747/55-57, 748/65, 750/ 89-91.

20. NM Grønne arkivkasser nr 19. "Concept til inventarium for Kunstkammeret 1690", fol. 7-8. De 39 kameer og gemmer er ikke anført på afgangslisten 1690-98 i inv. 1690 fol. 529-530.

21. Gundestrup 1991 I 738/150, 739/158, 748/61.

22. Ibid. I, 759/225-226, 774/477.
23. Ibid. 796/765 jf. Kladde til 1737 inventariet,

NM Grønne arkivkasser nr. 18, fol. 131

24. MR 1710,II, I, 86 jf. Gundestrup 1991, I, 645/ 70.

25. Christoph Becker: Vom Raritäten-Kabinett zur Sammlung als Institution. Zur Sammeln und Ordnen im Zeitalter der Aufklärung. Deutsche Hochschulschriften 1103, Frankfurt 1996, 3-43.

26. Genoptrykt i Michael Bernhard Valentini: Museum Museorum oder vollständige Schau Bühne.

2. Edition. Frankfurt am Main 1714, I. Anhang, $1-76$.

27. L.C. Sturm: Des geöffneten Ritterplatzes, worinnen die vornehmste ritterlich Wissenschaften, III, Raritäten-Und-Naturalien-Kammern, Hamburg 1707.

28. J.D. Major, op. cit., IV-V kap., 5-11. L.C. Sturm, op. cit. III kap., 15-18.

29. Sturm, op. cit., 9.-11. kammer, stk. 2-6, 36-39, 50-51.

30. Smml. Gundestrup 1991 I 213-417 med Kunstkammer inv. 1690, fol. 46-72.

31. Gundestrup 1991, I, XIX-XX. Liisberg 1897 87-99.

32. Bencard, Mogens \& Hein, Jørgen: "Die Preziosen des Gottorfer Herzogshauses. Eine private Kunstkammer" i Drees, Jan \& al.: Gottorf im Glanz des Barock, II: Die Kunstkammer, Schleswig 1997, 49-57, 162-224. Hertil Rosenborgs inv. 1718 fol. 294-360.18.

33. Hein; Jørgen: "Frederik V som samler. Kunsthåndværk fra det første Christiansborg. Om privat og offentligt i enevældens kongelige arv" i Jeppesen, Hans (et al): Søfart-Politik-Identitet. Festskrift til Ole Feldbæk, 1996, 245-266.

34. Rosenborgs arkiv: Protokol over det, der blev reddet ved Christiansborg Slots brand 1794 .

35. Inv. 1775 fol. 244-263 nr. 596, 612, 615-616, 624, 629-660, 672-677, 680-682, 684, 688, 699-702, 728, 785-818.

36. Jensen 1981, 48. 
37. RA DK Det kgl. Kunstkammer 39: 1775-1793 Inventarieregnskaber, forestillinger og korrespondance m. v. Hertil Sorø Akademis Bibliotek. Johan Bulows Manuskriptsamling. 18 Hoffet. 84 E 2: "Udtog af Rosenborg Slots Inventario, 1793.

38. Andrup, Otto: Den kongelige Samling på Rosenborg gennem hundrede Aar, I, 1933, 49.

39. Thomsen, C.J.: Kort Udsigt over Det kongelige Kunstmusaums forskjellige Afdelinger, 1844, 26-28 nr. 52-55, 29-32 nr. 60, 36 nr. 70.

40. Worsaae, J.J.A.: Optegnelser om Rosenborg-Samlingen i 25 Aar, 1886, 9, 23-29, 31, 52-57 samt Rosenborgs brevarkiv 14.4.1860.
41. Ifølge Worsaaes tilgangsliste i Rosenborgs arkiv skulle der udarbejdes en opgørelse over genstandene i henhold til "Cultusministeriets Resolution af 23de Dec. 1868". Dette synes aldrig at være sket. Tallet bygger på Rosenborgs inventarium fra 1877, der kun dækker udstillingen, samt en liste fra ét af magasinerne.

Jørgen Hein är museumsinspektør vid Rosenborg. Adr: De Danske Kongers kronologiske Samling,

Rosenborg, ØsterVoldgade $4 \mathrm{~A}$

DK-1350 Kobenhavn K

E-post: jh@dkks.dk

\section{ATT SLÅ VAKT OM TVIVLET I EN VÄRLD FULL AV AUKTORITET}

Carl-Axel Moberg (1915-1987) skrev sin "klassiker" i Svenska Museer när han fortfarande var museilektor vid Statens Historiska Museum i Stockholm. Samma år, alltså 1957, utnämns han till chef för Arkeologiska museet i Göteborg. Åren 1960-1979 verkar han som professor i arkeologi vid universitetet där. Och som sådan också som en viktig introduktör i Norden för angloamerikanska och franska idéströmningar. Carl-Axel Moberg var internationalist, humanist och stor inspiratör för yngre kolleger. Som en röd tråd i hans vetenskapliga och litterära författarskap löper respekten för de mänskliga rättigheterna och för det personliga ansvaret som forskare och pedagog.

"Pedagogik och propaganda är två populära ord som numera i allra högsta grad ingår i museimäns ordförråd", lyder hans inledning. Detta ordförråd, 45 år senare, innehåller förvisso pedagogik, numera och i allt högre grad uttryckt som det livslånga lärandet. Propagandan har kanske inte längre ett eget ministerium. Men väl som i Berlusconis Italien ett helt kabinett. Och de Olympiska Spelen är propaganda i kolossalformat.

Det mediavridna samfundet, som förändrat museernas roll, förstärker samtidigt det principiellt angelägna i vad Moberg skrev. För honom är museerna först och främst förmedlare av kunskap - arkeologiskt i ordets egentliga bemärkelse är ett museum ej genom att det äger ett arkeologiskt material, utan endast i den mån dess verksamhet har med arkeologisk vetenskap att göra.

När Moberg nämner 1943 och Historiska museet åsyftar han den stora utställningen Tiotusen år $i$ Sverige. En utställning som nu vore värd en egen mässa.

En utställning är som en dialog mellan museet och besökaren. Men, menade Moberg, den som ställer ut får inte gömma sig bakom museets anonymitet - den aktuella frågan om curatorer.

Och som vågor som slår mot en strand - avsaknaden av god och öppen museikritik, då som nu.

... att slå vakt om det fruktbärande tvivlet i en värld full av auktoritet.

I mitt litterära husapotek finns sju böcker. En av dem är Carl-Axel Mobergs Den långa stubinen (1977), en annan Tage Danielssons Tankar frän roten (1975). De båda samhällsbyggarna förenas i sin starka tro på tvivlet.

"Tvivlet är all kunskaps grund", skrev den sistnämnde. I döda poeters sällskap vidgas perspektiven och fördjupas framtidstron.

Erik Hofrén 